\title{
Adoption and Implementation of Sustainable Development Goals (SDGs) in China-Agenda 2030
}

\author{
Siming Yu ${ }^{1}$, Muhammad Safdar Sial ${ }^{2,3}$, Dang Khoa Tran ${ }^{3}$, Alina Badulescu ${ }^{4} \oplus$, \\ Phung Anh Thu ${ }^{5, *}$ ) and Mariana Sehleanu ${ }^{4}$ \\ 1 Business School, Hubei University, Wuhan 430062, Hubei, China; yusiming19890622@163.com \\ 2 Department of Management Sciences, COMSATS University Islamabad (CUI), Islamabad 44000, Pakistan; \\ safdar.sial786@gmail.com \\ 3 Institute of Business Research, University of Economics Ho Chi Minh City, \\ Ho Chi Minh City 700000, Vietnam; khoatd@ueh.edu.vn \\ 4 Department of Economics and Business, Faculty of Economic Sciences, University of Oradea, \\ 410087 Oradea, Romania; abadulescu@uoradea.ro (A.B.); mavancea@uoradea.ro (M.S.) \\ 5 Faculty of Finance and Accounting, Nguyen Tat Thanh University, Ho Chi Minh City 700000, Vietnam \\ * Correspondence: pathu@ntt.edu.vn
}

Received: 24 June 2020; Accepted: 2 August 2020; Published: 4 August 2020

check for updates

\begin{abstract}
The present research is conducted on the Chinese corporate sector and raises the basic questions associated with the adoption and implementation of corporate disclosure practices such as SDGs. The sample for this research consisted of 100 Chinese companies, which are listed in the Shanghai Stock Exchange from 2016 to 2018. For this purpose, content analysis is developed. More specifically, a quantitative approach is applied to quantify and identify certain contents or words in the given text. Our results show that Chinese companies seem to be more focused on certain aspects of the UN SDGs at the cost of others, but the overall situation is, at best, not encouraging. The focus of attention of Chinese companies seems to be infrastructure development, industrial innovation, and economic growth, along with the provision of a dignified and respectable working environment, affordable and clean energy, and peace, justice, and strong institutions. The results can be used as guidelines by Chinese companies to determine the actual presence or absence of SDGs implementation inside the process of value creation as an integral part of their practices about corporate disclosure. The main contribution of this research relates to the analysis of the adoption and implementation efforts to report SDGs and the contribution of such reporting towards the fulfillment of the UN Agenda 2030. This can be of interest to researchers working on the given topic. It is of utmost importance for government policymakers and corporate decision-makers, who want to support companies that are contributing towards the achievement and adaptation of SDGs as part of their overall objectives.
\end{abstract}

Keywords: sustainable development goals; adoption and implementation; China; agenda 2030

\section{Introduction}

Currently, China stands in second position in the world in terms of its Gross Domestic Product (GDP) and China has been progressing at a very fast pace when it comes to industrialization and urbanization. Even though the achievements are outstanding, they come at an expense of polluting mother nature [1,2]. A report issued by the Asian Development Bank states that out of the ten most polluted cities, seven of them were in China. In addition to that, barely 1\% of China's 500 cities meet the air quality standards given by the World Health Organization. The Eastern and Central parts of China recently have been hit with haze and have deteriorating effects on the health of humans. The local and 
central Chinese government has introduced a set of laws and policies to protect the environment from pollution due to the extreme threat to the environment posed by escalating pollution $[3,4]$. The Chinese Government has introduced the legal system of environmental and resource protection with Chinese attributes yet, nevertheless, environmental standards in China have not been enhanced because of a lack of strict actions and several other reasons [5]. The United Nations has put to the front environment pollution as one of the most deprecatory blockades to achieving the Sustainable Development Goals in China.

The 2030 Agenda for sustainable development has its basis on the Millennium Development Goals (MDGs), and above MDGs, is promoting a rather new dimension of worldwide sustainable development, especially with the commitment to addressing global development problems and providing enabling conditions for developing countries to play a major role in global development. The 2030 Agenda had a very positive influence on the Chinese economy. For one thing, the agenda defines the common responsibilities and the specific responsibilities for different countries of the world. Secondly, it works hand in hand with China's promotion of "The Belt and Road" Strategy. Thirdly, the said agenda is beneficial for the better development of ideas and sharing experiences with other countries and the soft power of China is strengthened. Conversely, if we want to fulfill the obligations and objectives of the 2030 Agenda for sustainable development, there are several obstacles present. One of the leading challenges is the overall economical evolution. If we look at it from an economic development viewpoint, the conventional economic growth-driving practices, which are dependent on low-cost resources and factor inputs, are notably weakened.

China is stepping forward to a new era of economic revolution where new forces to drive economic growth are to be found. Another challenge is that China is restricted by the defects of social development and environmental issues. The third challenge is that China has limited ability in the current state of development, and our international responsibilities may be more than what we can fulfill. The demands for the country's implementation of the 2030 Agenda of sustainable development are greater if we look at it from an international perspective. In the post-2015 period, it is crucial for China to merge the basic three pillars of sustainable growth in a steady way and to facilitate the smooth transition of economic structural transformation into more value-added activities, and sectors will continue to play a major role in achieving continued global prosperity. A detailed framework needs to prepare that includes basic productive capacities, supports education and social development, and is sustainable environmentally. Looking at the specific responsibilities for the 2030 Agenda for sustainable growth, China has instigated "China's National Plan on Implementation of the 2030 Agenda for Sustainable Development" and formed an innovation demonstration zone and Green technology Banks for the execution of the said agenda. To make this work, the following work is needed: first, we need to strategically merge the 2030 Agenda with the 13 Five Plan; second, the Ministry of Foreign Affairs took the lead to provide institutional guarantee and brought together 43 departments for a coordination mechanism; third, for social promotion, the United Nations has hired 16 spokespersons for the corresponding targets to encourage these goals; fourth, dominant Chinese businesspersons will be employed in the China office of the UNDP to provide consultation using their influence; fifth, the social capital and investment of resources need to be utilized at their maximum potential; sixth, further cooperation from international entities is required.

The foundation of this research rests on the need for a detailed analysis of the adoption and implementation of SDGs in the context of China. The implementation status of such SDGs is only possible if the country can identify the extent of effort required for their effective implementation, which in turn, can be achieved by careful planning in the future. This planning becomes easier and more effective if the awareness of such disclosures is high amongst the corporate sector. This also enables planners to determine the exact path and map out the short- and long-term goals in this regard, along with the identification of right tolls, such as level of intervention by governing bodies. It is obvious from the analysis of the facts that even though the level of economic and social progress 
achieved by China can be considered as phenomenal, it is lagging far behind the developed countries when it comes to voluntary disclosure requirements such as SDGs.

Ye and Fues [6] highlight the important role China has played in bridging the gap between the developed and developing countries when it comes to the global sustainability agenda. China has shown great commitment to sustainability caused by not only adopting but also implementing "Sustainable Development Goals". One such example is the adoption and promotion of initiatives such as green development since 2013 as part of its policy documents. As per official government policy, China came up with a comprehensive policy framework to achieve Sustainable Development Goals by 2030 (Government of China 2016a). The main objective of such a framework is to address issues regarding social and environmental wellbeing, and SDGs are broken down into actionable targets to be achieved in a specific period.

The SDGs can also be incorporated into the development of a new and efficient business model, in which voluntary disclosures can be incorporated as an integral part. As a result, this will not only enhance the social and corporate reputation of firms adopting such models but will also ensure sustainable development. Sustainable development not only reduces the risks faced by business but also can reduce the impact on the environment and society, along with improvement in the efficiency of business processes. This is a novel concept but researchers have highlighted the limitation of actual empirical evidence in academic research which supports such a notion as SDGs with some exceptions [7]; in the case of the actual corporate world, the story follows the almost same path like PricewaterhouseCoopers [8]. However, very rarely have studies been conducted in China.

The present research is conducted on the Chinese corporate sector and raises the basic questions associated with the adoption and implementation of corporate disclosure practices such as SDGs. Do Chinese companies report SDGs?' To answer this burning question, we further formulated the four questions which retain different aspects of SDGs. First, which documents are used by companies to release information related to SDGs? Second, when was the first time these corporations initially mentioned SDGs? Third, which SDGs can be ranked as most cited amongst Chinese corporations? Fourth, can SDGs be considered as part of their business models?

We intend to answer the above questions by examining the corporate reports of Chinese companies' issues in 2016 to 2018 [9]. For the purpose of our research, we first bifurcate the annual reports denoted by (AR) reports, then, related to sustainability denoted by (SR), and Integrated Report denoted by the term (IR). We focus on the disclosures information that forms the SDGs by analyzing the abovementioned instruments of AR, SR, and IR via analysis of their basic contents, which point towards KPIs which, in turn, forms the bases for SDGs. We follow the underlying assumption that the level and contents of such disclosure are dictated by the industrial sector in which the corporation operates, within the Chinese economic context.

The sample for this research consisted of 100 Chinese companies, which are listed in the Shanghai Stock Exchange from 2016 to 2018. Our findings indicate a high level of disclosure; at the same time, we found that the in the case of the majority of companies, SDGs were not incorporated into their company-specific goals or business strategies. The disclosure mainly relates to the mention of voluntary disclosures in different reports issued by these companies. Our research can be considered as pioneering research on the given topic in the Chinese context and underlines the importance the SDGs have gained in recent times. Corporate social responsibility dictates that corporations disclose such information on voluntary bases and incorporate such reporting mechanisms into their larger business strategies, which also lead to value creation. Based on our research, we can safely conclude that in the case of China, the SDGs have gained significance as far as reporting mechanism is concerned, but there is still a long way to go when it comes to incorporating these into the strategic objectives of Chinese companies, and there is a lack of tangible evidence related to their adoption implementation as part of companies' overall objectives.

We have five sections of this study. Section 2 presents the theoretical background, research questions, and literature review. Section 3 presents the materials and methods. Section 4 has 
the results and discussions. Finally, the conclusion and policy implications and limitations can be found in Section 5.

\section{Theoretical Background, Research Questions and Literature Review}

\subsection{Theoretical Background and Research Questions}

Griggs and Nilsson [10] state that the legitimacy theory dictates that organizations can only survive if they maintain positive public perception, and along with this, the relationship between their corporate behavior and social expectations placed on them by the general public. Deegan [11] furthers this notion and points out the existence of a social contract between corporations and general society. This theory is widely accepted as it provides the underlying relationship between society and corporate social disclosures made by corporations [12]. This theory hypothesizes that businesses persistently seek to certify that they are operating with the social and cultural limits of a given society. This happens as businesses are economic entities that have to function within the social environment established by the network of organizations that change their conduct and compel them to fulfill the expectations placed on them $[13,14]$.

The organizations adopt the legitimacy theory as they go for voluntary disclosure of information which might impact society and its environment as a whole as they consider it their moral and social duty [11,15]. This external environment also forces organizations to adopt rules and regulations that are in line with the social and cultural environment in which they are operating. Keeping this in mind, organizations opt for integrated reporting along with adoption and implementation of SDGs as the main methods of managing this pressure and improving their transparency. This also results in an improvement of accountability with the organization, as their financial and non-financial reports are considered credible by stakeholders. According to [15], the organizations with a specific industry are expected to behave similarly when they face such pressures, commonly known as isomorphism phenomena. According to Ntim and Soobaroyen [16], the neo-institutional theory also lends weight to this argument, as it also states that organizations adopt local cultural values to legitimize themselves and their operations in the eyes of their stakeholders.

A corporation can achieve strengthen its legitimacy because of institutional pressures. These include laws or local regulations; normative pressures, which mainly include moral amenability or pressure of unions who want the organization to comply with their social and cultural norms; mimetic pressure, which forces the organization to mimic the behavior of existing organizations operating in a specific society [17]. Thus, the isomorphism results from both internal and external pressures.

The emergence of concepts relating to sustainability such as SDGs has enabled organizations to discriminate themselves from others when they adopt such measures as it improves their legitimacy in front of the public and stakeholders [7]. As it is evident from the literature that organizations are greatly influenced by external pressures, this study aims to empirically examine the level of disclosures set out by organizations in IR reports, considering the standard of IIRC and of SDGs. Therefore, the research questions set out specifically to address these issues are as follows. Do Chinese companies report SDGs? To answer this burning question, we further formulated the four questions which retain different aspects of SDGs. First, which documents are used by companies to release information related to SDGs? Second, when was the first time these corporations initially mentioned SDGs? Third, which SDGs can be ranked as most cited amongst Chinese corporations? Fourth, can SDGs be considered as part of their business models?

\subsection{Literature Review: Sustainable Development Goals (SDGs) Reporting}

Sustainable development is mostly thought of as a new concept related to corporate social reporting or responsibility, but in the case of China, it cannot be considered as a new concept because it directly relates to ancient Chinese concepts such as ecological civilization (生态文明).The concept 
of sustainable development came into the limelight in conjunction with beautiful China (美丽中国) vision, this vision was elevated to constitutional status in March 2018 after the National People Congress (NPC) meeting. The concept of ecological civilization relates to the Chinese belief set that nature needs to be respected and cared for rather than a resource that can be endlessly exploited for personal gains. This vision is the bases for "ecological socialism" and the main force behind the Chinese green development initiative. It has also been incorporated in the charter of the "Communist Party of China" in its eighteenth national congress in 2012. Kuhn [18] also attributes this concept to the formation of "Beautiful China", which mainly refers to the formation of policies to uphold the importance of environment and formation of policies by the government for its protection.

The "Beautiful China" concept was forged by Sichuan University, Chengdu, which proposed the Beautiful China Index, based upon the considering concerns of multiple stakeholders for the development and promotion of "sustainable development strategies" for the Chinese economy. Academic research has added various dimensions to this concept and has not only provided depth to this concept but has also lent its global dimension. The role of social media in the promotion of this concept has also been positive as it helped in the spreading of green knowledge. According to Wang and Lyv [19], the main sources of climate-related information were the social forum of WeChat and television. This survey also recognized an increasing role played by NGOs in this respect as compared to half a decade earlier [19].

The definition of sustainable development for purpose of this research is limited to the process of transformation of natural resources without degradation in such a way that they can also be utilized by future generations for their development, e.g., leading to cohesive economic, social, and environmental development [20]. The main assumption of the above-stated definition relates to the use of natural resources in such a way that they are not depleted beyond the point of replenishment and without deteriorating the environment of the area in which the business operates. The present generation must keep in mind that future generations also have the right to use these resources as well [21].

In this context, the concept of "intergenerational justice" is of utmost importance as this concept mainly relates to preserving the environmental and ecological resources for generations to come. This concept adheres to the efficient use of natural capital. This can only be achieved by harmonizing economic activities with natural balance. This concept is far deeper than that of "sustainable development" as the "sustainable development" concept only addresses present needs, but this concept also considers the requirements of future generations. This concept dictates that the present generation must consider that the consequences of their mismanagement of resources will be faced by their future generations [22]. This concept is also endorsed by many international organizations such as the "World Commission on Environment and Development", who issued one such report under the title "Our Common Future" [23]. This theme was also adopted by Earth Summit 1992 and as a result, the program under the title of "Agenda21" was established [24]. The "Millennium Development Goals" set up by the U.N.O under its "Millennium Declaration" can also be attributed to this concept [25]. The main aim of these was to enable the world to coup up with the environmental social challenges of the 21st century until 2015. In 2002, in Johannesburg, South Africa, followed by Rio de Janeiro, Brazil, in 2012, the provisions of Earth Summit 1992 were not only ratified but were also renewed [26]. The participants of the Rio summit, also known as Rio+20, also expressed their desire to promote the idea of sustainable development not only in the context of the economic sense, but also in sociocultural settings as well. Sustainable Development Goals (SDG) replaced Millennium Development Goals in 2015 and the 2015 Agenda was replaced by that of 2030 [27]. The main agenda of SDGs 2030 is poverty elimination, provision of favorable and decent living conditions for people all over the globe by ensuring world peace, and sustainable economic and social development. This is a plan for global development. The aspect related to sustainable development seems to be the thought task now due to prevailing negative attitudes of businesses and their leaders.

The main issue pointed out by Raszkowski [28], is related to the oversimplification of this phenomenon and wishful thinking that it can easily be achieved, while it is more of a social issue 
as mentioned earlier. To fulfill the objectives of SDGs, one has to keep in mind that the awareness level relating to the ecological has to be raised (Judson [29], Caputo and Veltri [30]) around the globe. This dimension of SDGs is the linchpin when it comes to achieving the SDGs as it impacts all the other aspects, including poverty, social development, and world peace as well. It is safe to assume that sustainable development cannot be substituted by traditional environment protection activities as it is not only concerned with these but also includes harmonizing the economic and social development at the global level, as only then, the environment can truly be protected for our future generations, in such a way that they can also take full advantage of natural capital. Nonetheless, the eco-friendly characteristic is of vital significance for the quality of human lives as well future human generations [31].

\subsection{Sustainable Development Goals (SDGs) Agenda 2030}

The political declaration, 17 comprehensive objectives, 169 targets, separate ways of executions, and follow up actions are a part of 2030 sustainable development. This can be identified as a strategic plan for the achievement of global sustainable development in line with the Millennium Development Goals (MDGs). The vision for future worldwide development is set by the 2030 Agenda for Sustainable Growth, which calls attention to the UN Charter and the Universal Declaration of Human Rights. It also focuses on the dedication to make the world a place that eliminates poverty, hunger, fear, and violence. It lays stress on making the world a place where the basic human rights and rule of law are abided by and to realize inclusive and sustainable economic growth, and the sustainable use of natural resources. There are 17 core objectives of the 2030 Agenda, which are known as SDGs.

Goal 1. No poverty. Out of the total population of the world, around thirteen percent of people are living below the poverty belt. We need to eliminate extreme poverty and decrease the poor population by $50 \%$ in different countries; according to their policies and national standards, basic services are to be provided universally, and finally, the groups which are at risk and their ability to hold out against natural disasters and economic and social risk needs to be improved by 2030.

Goal 2. Zero hunger. Presently, out of the whole world's population, around 790 million people suffer global hunger and $\frac{1}{4}$ children are malnourished. To achieve global food security is one of the major goals which needs to be achieved by 2030. We need to improve people's nutrition and promote sustainable agriculture so that people can have safe, nutritious, and abundant food, resultantly doubling the incomes of agricultural producers and agricultural productivity.

Goal 3. Good health and wellbeing. The global maternal mortality needs to be reduced to below 70 in every 100,000, with the mortality rate of children needing to be lowered to below 25 per 1000 . The targets of this goal pay key attention to infectious and chronic diseases. HIV/AIDS, Tuberculosis, malaria, and tropical epidemics are needed to be contained and the mortality of non-infectious diseases is to be reduced by $1 / 3$.

Goal 4. Quality education. The elimination of the education gap between males and females by providing them with equal opportunity to gain primary and pre-school education, along with ensuring that they also continue towards education at the primary and secondary level to enhance their existing numeracy capabilities, is cited as one of the most important goals of 2030. This will not only promote education but will also provide the general public with an opportunity to further their higher education.

Goal 5. Gender Equality. The endorsement of women politicians or ensuring their participation in politics is considered a vital indicator of gender equality in contexts at both local and international levels.

Goal 6. Clean water and sanitation. Access to clean drinking water and hygiene facilities is considered as one of the emphasized points.

Goal 7. Affordable and clean energy. By 2030, the general public should have access to affordable and renewable sources of energy as by then, it is estimated that global energy efficiency in respect to renewable sources would double and thus, overall energy production will also follow that trend.

Goal 8. Decent work and economic growth. It is estimated that an increase in GDP of the underdeveloped countries will be maintained at a minimum level of $7 \%$ which will enable the 
development and growth of small and medium scale businesses, thus, providing the general public with dignified employment and equal employment opportunities for all. Along this line, elimination of child labor by 2025 is also considered as a priority.

Goal 9. Industry, innovation, and infrastructure. Development of industry is mainly dependent upon the development of infrastructure and since industrial development is considered as the backbone of economic and social development, it can only be sustained via innovation [32]. The UN's report of 2015 stated that sea transportation around the world accounted for 2.7 trillion USD, which amounts to $3.5 \%$ of GDP of the whole world. The main issue here is the fact this presents a steep challenge for underdeveloped countries and especially for those who are landlocked [33]. The above-cited report also indicated that share production value addition rose from $15.3 \%$ in 2005 to $16.2 \%$ in 2016 .

Goal 10. Reduced inequalities. The UN has stated that sustainable development can only occur if 'equality' exists [32]. The issue seems to be that inequality is not universal and tends to change from country to country. The reports from the period of 2008 to 2013 indicate rapid increment in the per capita income of $40 \%$ of the counties which were considered as poorest as compared to the national average.

Goal 11. Sustainable cities and communities. Around the globe, the population growth trends in both urban and rural centers are, at best, unsatisfactory [34]. The growth rate amongst the urban population is alarming [35,36]. The UN is aiming for sustainable urban and rural communities to improve the living standard of the general population by improving the sustainability index [37,38]. The UN reports indicate that almost 5 billion people will be living in cities by 2030; at present, it stands at $54 \%$ of the world population.

Goal 12. Responsible consumption and production. Most people tend to blame manufacturers for not showing reasonable behavior towards the use of natural resources, but the blame also lies with the consumers as well, as they also need to show responsibility towards the consumption of resources [39]. The UN has been working tirelessly to produce a responsibility framework for both manufacturers and consumers and has launched several awareness campaigns along with educating masses [40]. According to reports, on average, the consumption of material has increased from 1.2 to $1.3 \mathrm{~kg}$ per unit of GDP in a decade in the first decade of the 21st century; during this period, consumption of material rose from 48.7 billion tons to 71.0 billion tons globally [41].

Goal 13. Climate action. The first and foremost point of the global agenda set by the UN is said to be climate change. The UN and almost all leading international organizations have suggested climate change as a major factor for sustainable global development and have, thus, included it as a foremost priority [42]. Almost all aspects of human life are directly impacted by climate change [43]. According to the United Nations [41], the rapid increase in global temperature will have catastrophic consequences on the global climate, as global temperature increased by 1 centigrade by 2016, resulting in an unprecedented change in global climatic patterns. Many nations are now switching to green energy or renewable energy to preserve the climate and slow down this increase in global temperature [41].

Goal 14. Life under water. In total, $10 \%$ of global coastline needs to be declared as a conservation area to protect marine life.

Goal15. Life on land. Emphasis has been placed on the preservation of biodiversity along with ecosystems.

Goal 16. Peace, justice, and strong institutions. The idea of the democratic system, the rule of law, peace, inclusiveness, and corruption-free practices are also considered as a major part of the government's agenda (Ministry of Foreign Affairs, 2016).

Goal 17. Partnership for goals. To achieve the goals of sustainable development, the UN has introduced the concept of global partnerships [44,45]; this is also taken into consideration in its mission [33]. The amount of ODA (official development assistance) from the OECD to the UN increased by $8.9 \%$ to 142.6 billion USD in 2016 according to official statistics of the UN, which is considered by many as a positive step towards the formation of and suitability of the global partnership initiative [41,46]. 


\section{Materials and Methods}

This part of the research explains the methods used by the researchers to conduct the present study. It is further divided into three parts. The first part explains how the sample was obtained, the second encompasses the data collection procedure and methods, and the third one explains the research methodology.

\subsection{Sample and Data Collection}

The sample size consisted of 100 Chinese companies, which are listed on the Shanghai Stock Exchange from 2016 to 2018. The disclosures related to SDGs were evaluated by studying several documents. The analysis consisted of (i) the Annual Report, denoted by (AR), which is a basic requirement of any publicly-traded company and is considered as mandatory as it contains financial results of issuing company [47]; (ii) the second document which we analyzed is the Sustainability Report, denoted by (SR), and this not only includes a snapshot of financial performance but also highlights the efforts or resources which the company has voluntarily dedicated to the preservation of the environment and spent on other social causes [48]; (iii) the third stage consisted of the analysis of the Integrated Report, denoted by (IR), as this report includes the summary of the efforts the company has put in addressing the issues such as governance, strategic objectives, both financial and non-financial performance of the company along with a summary of its prospects. This addresses the external stakeholders and the general society. Such reports not only enhance the social image of the company, but also lead to better financial performance in both the short and long term [49].

We also considered the documents that contained the Non-Financial Statement (NFS) to enhance our analysis; these NSF documents are sometimes presented as an extra report or are attached to one of the earlier mentioned documents such as AR, SR, and IR. We compiled the above-stated data through the company websites and the main reports were Annual Reports, Integrated Reports, Sustainability Reports, and Non-Financial Statements. A total of 100 documents from websites of the companies were observed to compile the data during the years 2016 to 2018.

\subsection{Research Method}

As stated above, the main aim of this research was the adoption and implementation of SDGs in Chinese listed companies. For this purpose, content analysis was developed. Content analysis is a widely used method to detect information within written texts. Frequency of ideas, through phrases, themes, and words, are identified using this theoretical analysis approach. More specifically, a quantitative approach is applied to quantify and identify certain contents or words in the given text. According to Krippendorff [50], content analysis is a research technique for making replicable and valid inferences from texts (or other meaningful matter) to the contexts of their use. Tagesson and Blank [51] and Lee and Barker [52] also supported the use of the content analysis technique for studies linked to company disclosure through corporate websites.

The data were structured and developed, based on the research questions in Section 1 and content analysis was developed to examine (i) the document(s) most of the Chinese companies use to provide information regarding their SDGs; (ii) the time when the companies began to report information regarding their SDGs; (iii) which SDGs can be ranked as most cited amongst Chinese corporations; (iv) can SDGs be considered as part of their business models?

\section{Results}

This section provides analysis and research results.

As the first step of our analysis, Table 1 shows a reporting package for the companies in our sample (not specifically linked to SDG disclosure) but is useful to present the general reporting practices and analyzed documents within large Chinese companies. In Table 1, thirty companies (30\%) gave an AR, while just ten companies presented an IR (10\%). Twenty-four companies $(24 \%)$ show SDGs in their 
sustainability reports and thirty-six (36\%) companies present SDGs in non-financial reports. Figure 1 also represents the reports to obtain information about SDGs.

Table 1. List of reports to get information about SDGs.

\begin{tabular}{ccccccc}
\hline Reports & Coding & $\mathbf{2 0 1 6}$ & $\mathbf{2 0 1 7}$ & $\mathbf{2 0 1 8}$ & Number & Percentage (\%) \\
\hline Annual Reports & AR & 7 & 10 & 13 & 30 & 30 \\
Integrated Reports & IR & 3 & 4 & 6 & 10 & 10 \\
Social Responsibility & SRR & 6 & 8 & 10 & 24 & 24 \\
Reports & NFS & 10 & 11 & 15 & 36 & 36 \\
Non-Financial Statements & & & & 100 & $100 \%$
\end{tabular}

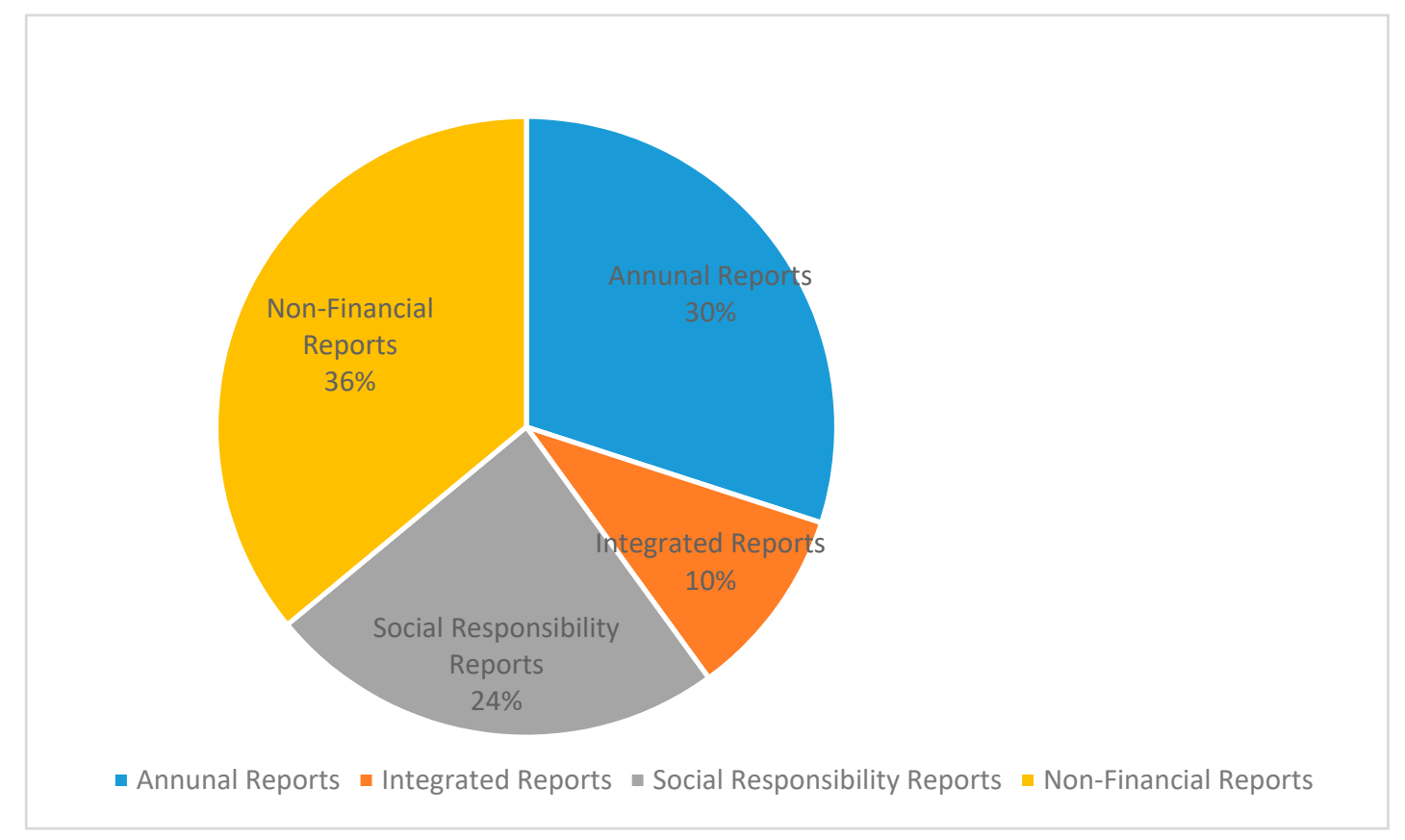

Figure 1. List of reports to get information about SDGs.

Table 2 describes the analysis of commonly mentioned SDGs within the Enlarged Reporting Packages (the years 2016-2018). Column 1 shows the list of 17 SDGs, the following column lists the number of companies that disclosed the information about the respective SDGs with related percentages, while the last two columns represent the unit of analysis and reports for analysis.

Table 2 describes goal number 9 as the most disclosed SDG, that is "industry, innovation, and infrastructure", which means that most of the companies (26\%) in our sample considered industry innovation and infrastructure development. The next most important goal is goal number 19 "decent work and economic growth", which means that $23 \%$ considered improvement of labor conditions and economic growth. Then, goal number 7, "affordable and clean energy" $(20 \%)$ and goal number 16 , "peace, justice, and strong institutions". Figure 2 also represent the SDGs mentioned in analyzed reports. 
Table 2. SDGs mentioned in analyzed reports from 2016-2018.

\begin{tabular}{|c|c|c|c|c|}
\hline SDGs & Number & $\%$ & Unit of Analysis & Reports for Analysis \\
\hline G 1. No Poverty & 30 & 10 & \multirow{18}{*}{ Thematic } & \multirow{18}{*}{$\begin{array}{c}\text { Annual Reports } \\
\text { Integrated Reports } \\
\text { Social Responsibility Reports } \\
\text { Non-Financial Reports }\end{array}$} \\
\hline G 2. Zero Hunger & 12 & 4 & & \\
\hline G 3. Good health and wellbeing & 9 & 3 & & \\
\hline G 4. Quality Education & 18 & 6 & & \\
\hline G 5. Gender Equality & 6 & 2 & & \\
\hline G 6. Clean water and sanitation & 12 & 4 & & \\
\hline G 7. Affordable and clean energy & 60 & 20 & & \\
\hline G 8. Decent work and economic growth & 69 & 23 & & \\
\hline $\begin{array}{l}\text { G 9. Industry, innovation, and } \\
\text { infrastructure }\end{array}$ & 78 & 26 & & \\
\hline G 10. Reduced inequalities & 6 & 2 & & \\
\hline G 11. Sustainable cities and communities & 24 & 8 & & \\
\hline $\begin{array}{l}\text { G 12. Responsible production and } \\
\text { consumption }\end{array}$ & 15 & 5 & & \\
\hline G 13. Climate action & 15 & 5 & & \\
\hline G 14. Life below water & 9 & 3 & & \\
\hline G 15. Life on land & 6 & 2 & & \\
\hline G 16. Peace, justice, and strong institutions & 54 & 18 & & \\
\hline G 17. Partnership for goals & 27 & 9 & & \\
\hline Total & 300 & 100 & & \\
\hline
\end{tabular}

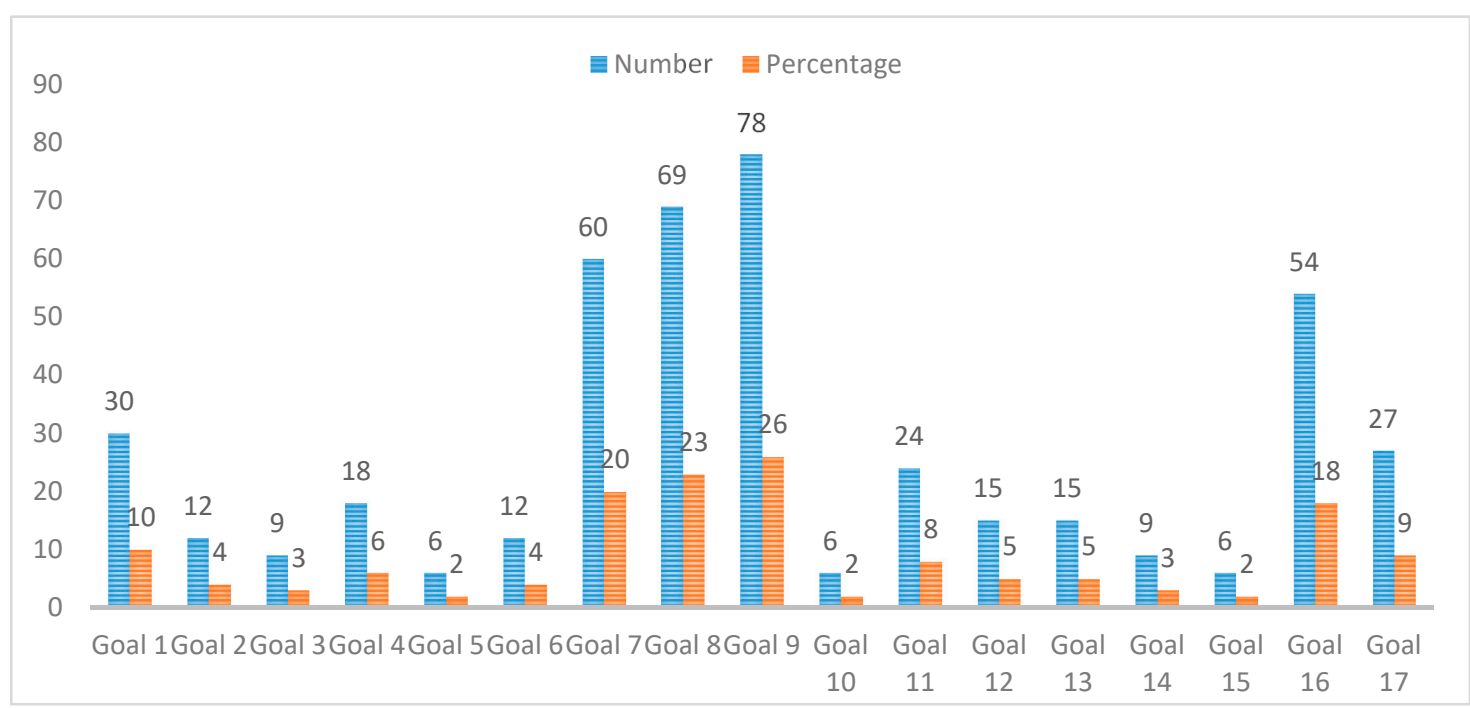

Figure 2. SDGs mentioned in analyzed reports.

It was also pertinent to examine how SDGs are considered by the companies in our sample. Beyond the mentions in the documents, it was also interesting to see what types of disclosures were given by the company in this regard. Table 3 describes how the companies revealed information about their SDGs, separating different policies of the companies into (a) the simple reference to the SDGs in a document or a SDGs-dedicated section identified in specific sections within the documents and (b) the conclusion to relate the SDGs to specific company objectives; (c) business models are related to the SDGs (d) that have clearly defined specific KPIs associated with the SDGs, or (e) have disclosed an understanding between the GRI and SDGs.

Table 3. The specific section provided information about SDGs.

\begin{tabular}{lc}
\hline \multicolumn{1}{c}{ Reports } & Percentage (\%) \\
\hline Specific documents in reports related to SDGs & 74 \\
Company objectives related to SDGs & 56 \\
Business model related to SDGs & 16 \\
KPI related to SDGs & 14 \\
Link between GRI and SDGs & 4 \\
\hline
\end{tabular}


Table 3 shows that $74 \%$ of the companies, i.e., the majority in our sample, describe their commitment to the SDGs by creating a specific section in their document(s). Additionally, $56 \%$ of the companies out of 100 in our sample linked their company goals to the SDGs, signifying the decisions they implemented to achieve the respective goals. At the same time, a very small number of firms (16\%) link their KPIs to SDGs and $14 \%$ of firms' business models related to SDGs. Only $2 \%$ of companies included in our study showed a relationship between their GRIs and SDGs. Figure 3 also represent the specific section provided information about SDGs.

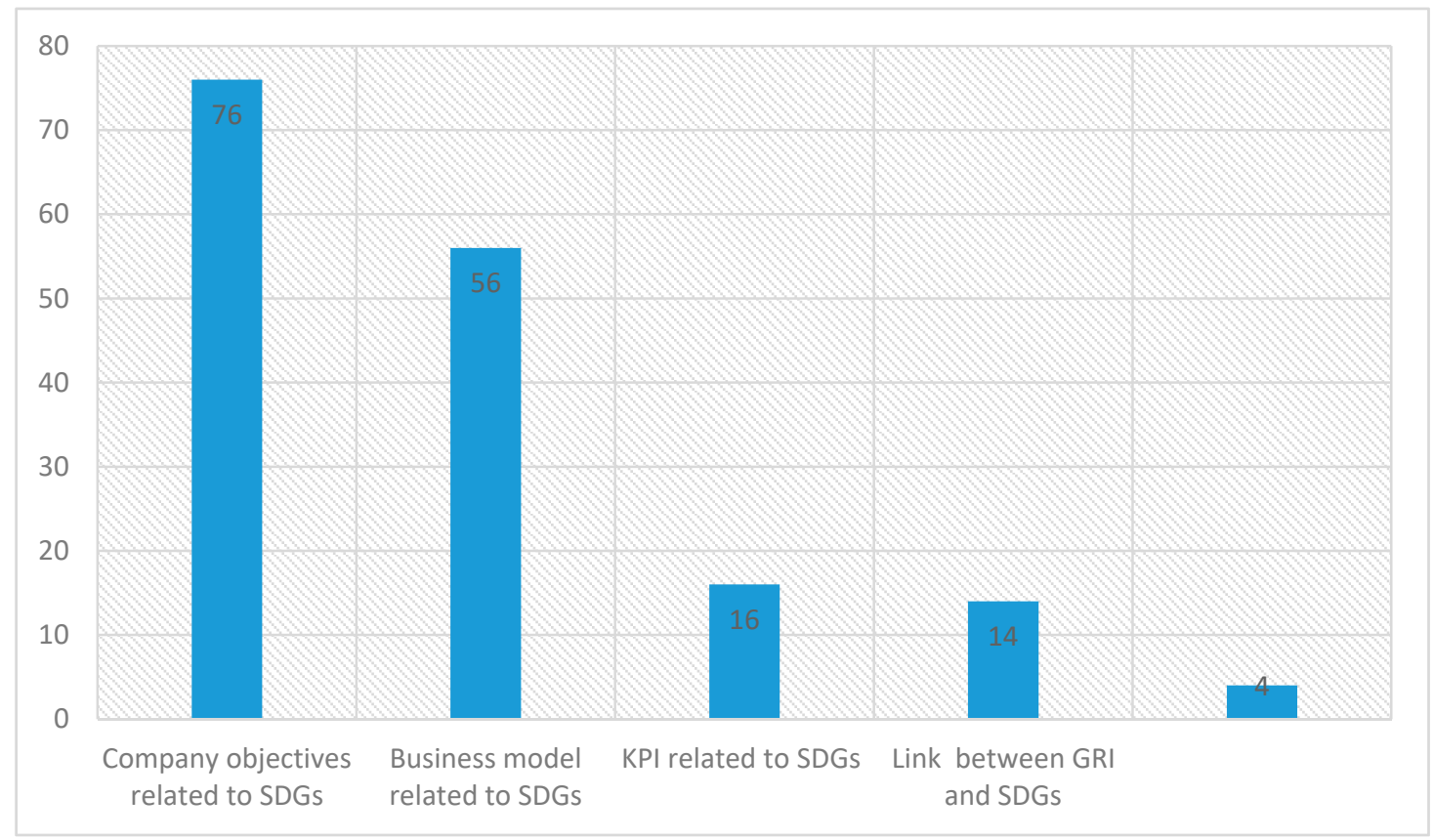

Figure 3. The specific section providing information about SDGs.

Table 4 represents yearwise SDGs in their analyzed reports; twenty-three percent of the organizations included in our sample began to release information about the SDGs in 2016, which is the first year that the 17 goals we reset, while most of the organizations mentioned the SDGs for the first time in 2017 (33\%) and in 2018 (47\%). Figure 4 also represent the yearwise SDGs mentioned in the analyzed reports.

Table 4. Yearwise SDGs mentioned in the analyzed reports.

\begin{tabular}{ccc}
\hline Year & Total Number of SDGs & Percentage (\%) \\
\hline 2016 & 60 & 20 \\
2017 & 100 & 33 \\
2018 & 140 & 47 \\
\hline Total & 300 & $100 \%$ \\
\hline
\end{tabular}

The results of the present study are not much different from those previous ones, as most of the studies had earlier observed that businesses around the world are failing to follow the basic guidelines of the UN SDGs [53]. When it comes to implementation of the UN SDGs, one of the reports concluded that the private sector needs to cooperate with governments in this regard to ensure that the main goals of the UN SDGs are met with time, as it has been estimated that an investment gap of almost 3 trillion USD annually will arise in the next decade [54]. Still, less than 50\% of global businesses seem to focus any attention on UN SDGs. Amongst leading global companies, only $36 \%$ of the companies tend to hire sustainability professionals. 


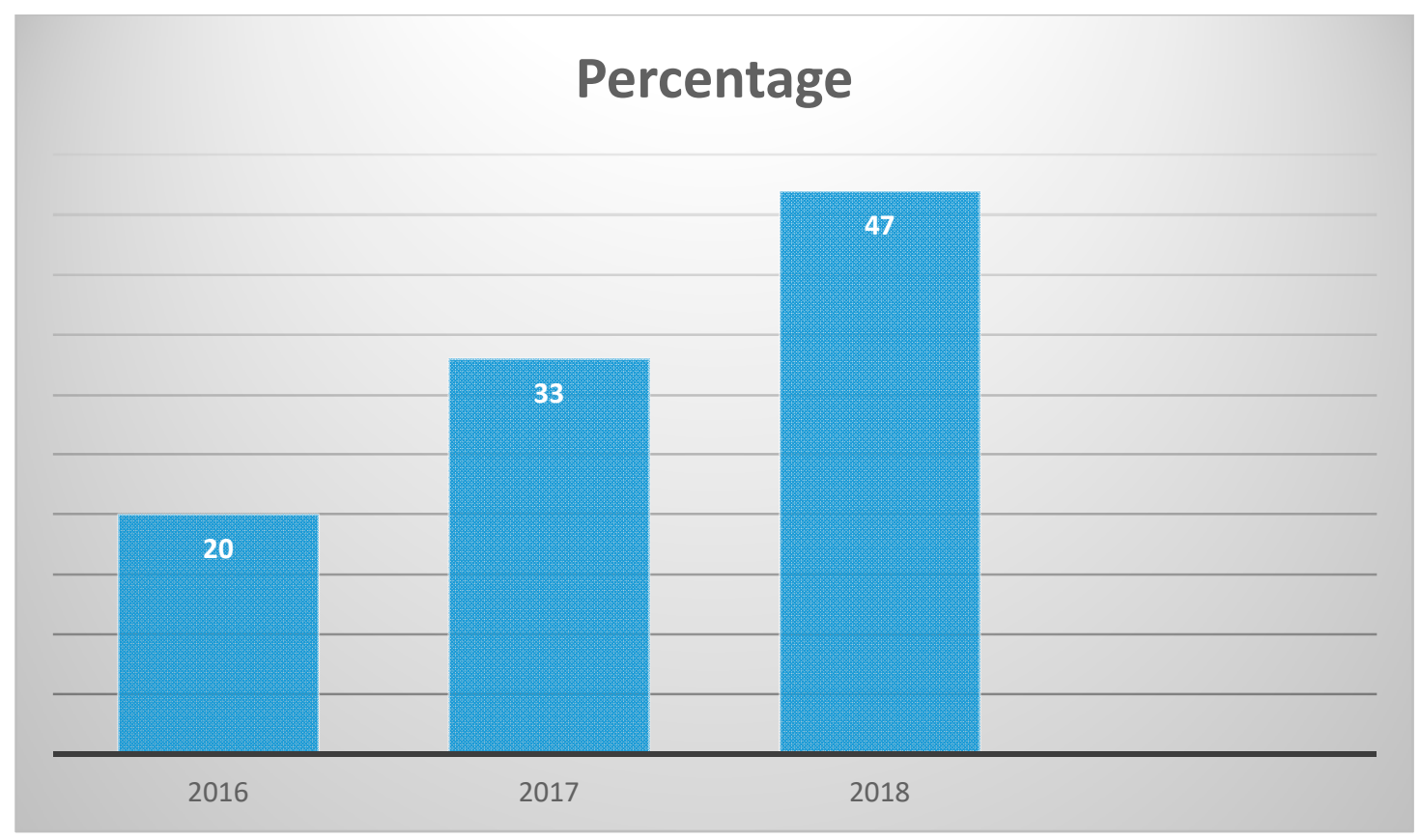

Figure 4. Yearwise SDGs mentioned in the analyzed reports.

Another study conducted on corporate citizenship by sustainability consultancy discovered that most of the businesses did not pay much attention to the abovementioned goals and as per the previous finding, it is clear that $81 \%$ of the success of the SDGs depends upon private businesses, but also, most businesses continue to ignore UNDGs [55]. To summarize, we can say that according to our research, Chinese companies seem to be more focused on certain aspects of the UN SDGs at the cost of others, but the overall situation is, at best, not encouraging. The focus of the attention of Chinese companies seems to infrastructure development, industrial innovation, and economic growth, along with the provision of a dignified and respectable working environment, affordable and clean energy, and peace, justice, and strong institutions, but there seems to lack of concern for "Climate change", "Marine life", and "Improvement in Quality of education". Our study also indicated that most of the large multinational companies do not pay much attention to the UN SDGs at all.

\section{Conclusions, Policy Implications, and Future Research}

The main motivation of this study was to provide evidence on the adoption and implementation of SDGs, in the context of voluntary disclosure policies followed by Chinese companies. SDGs are considered as basic guidelines for implementation and they provide guidelines for both corporations and governments for prospered economic, social, and environmental future [56] (p. 1657). Their significance can be ascertained by the fact that many commercial organizations are in the process of incorporating them into their strategic business objectives. These companies are providing detailed disclosures regarding SDGs as part of their annual corporate reports. Besides this aspect, it has recently become one of the more popular topics of academic research.

This pioneering research aims to contribute by offering empirical evidence regarding the adoption and implementation of SDGs disclosure amongst Chinese companies. We analyzed the extent of this disclosure and forms of this discourse, i.e., is it separate from embedded in existing reports using the reports published by our sample companies. The mention of SDGs in the AR, SR, IR, and NFS. Our results show that Chinese companies seem to be more focused on certain aspects of UN SDGs at the cost of others, but the overall situation is, at best, not encouraging. The focus of the attention of Chinese companies seems to infrastructure development, industrial innovation, and economic growth, along with the provision of a dignified and respectable working environment, 
affordable and clean energy, and peace, justice, and strong institutions. The results can be used as guidelines by Chinese companies to determine the actual presence or absence of SDGs implementation inside the process of value creation as an integral part of their practices about corporate disclosure.

The main contribution of this research relates to the analysis of the adoption and implementation efforts to report SDGs and the contribution of such reporting towards the fulfillment of UN Agenda of 2030. This can be of interest to researchers working on the given topic. It is of utmost importance for government policymakers and corporate decision-makers, who want to support companies that are contributing towards the achievement and adaptation of SDGs as part of their overall objectives [56].

In the case of China, the many objectives set out in SDGs form parts fundamental political agenda. China has enacted several environmental standards and incorporated a series of legal reforms to address social issues such as education, management natural resources, health care, and social security. Which are fully aligned with the goals set under the SDGs and the UN's 2030 Agenda? It can be safely assumed that the internationalization of SDGs can mainly be attributed to China. One of the experts of Tsinghua University equated this 15-year international plan to the series of five-year plans set out by the Chinese government to achieve economic and social success. The Chinese national plan for implementation of Agenda 2030 is considered a key policy document that is guiding the Chinese efforts to achieve SDGs in a time-efficient manner. This document about SDGs was published and adopted in September of 2016 in New York. Furthermore, China also endorsed the Paris Accord within one year of its signing during the 21st (COP) of the (UNFCC), which took place in December 2015. This shows the strength and commitment of the Chinese government towards the achievement of a sustainable future. This can also be ascertained by the commitment of the Chinese government at the national level, as it passed a series of reforms in local and national legislation during the National People's Congress meeting held in March of 2018. The scope and powers of the Ministry of Environment were enhanced, and it was converted into the Ministry of Ecology and Environment (生态环境部). It was handed additional responsibilities of assessing and countering threats of climate change as well. The Ministry of Land and Resources (自然资源部) was also created because of these reforms to strengthen the Chinese transition from conventional economy to the sustainable economy.

The implications of this study are not limited to academic circles but are also of use for the corporate sector and other stakeholders. These results provide basic guidelines for corporate reporting professionals on the main contents of their corporate reports and the best practices they should follow. The results also guide individual and corporate investors, credit rating agencies, and asset managers of different mutual funds, as nowadays the disclosure of SDGs is also considered as part of corporate risk profile ratings.

The major limitations of the present study are stated as under:

The first limitation mainly relates to the limited size of sample companies and the fact that these companies belong to China, so when generalizing the results, one has to keep in mind that generalization of these results may not apply to other regions as the companies shared country-specific characteristics. In the future, researchers can extend the sample size and conduct similar studies using cross-country corporate data. Such research works can be conducted on a longitudinal basis for determining the level of such disclosures over a specific time. Secondly, the scope of the study was limited to analyzing the disclosures related to SDGs and the performance of organizations in terms of advancement SDGs was not assessed; in the future, this can be done by conducting similar studies on a longitudinal basis. The third limitation is mainly associated with non-consideration of organizational factors such as the size of the company, several employees, size and composition of the board, economic resources of companies, their financial performance, and performance related to sustainability, etc. In the future, researchers can incorporate these factors in their research by considering such factors. They can also analyze the impact of these factors on the motivation for such disclosures, using quantitative research methods. 
Author Contributions: All the authors contributed to conceptualization, formal analysis, investigation, methodology, writing-original draft, and writing-review \& editing. All authors have read and agreed to the published version of the manuscript.

Funding: This research received no external funding.

Conflicts of Interest: The authors declare no conflict of interest.

\section{References}

1. Tao, M.; Chen, L.; Su, L.; Tao, J. Satellite observation of regional haze pollution over the North China Plain. J. Geophys. Res. Space Phys. 2012, 117, 117. [CrossRef]

2. Vo, X.V. Do foreign investors improve stock price informativeness in emerging equity markets? Evidence from Vietnam. Res. Int. Bus. Finance 2017, 42, 986-991. [CrossRef]

3. Li, L.; Xia, X.; Chen, B.; Sun, L. Public participation in achieving sustainable development goals in China: Evidence from the practice of air pollution control. J. Clean. Prod. 2018, 201, 499-506. [CrossRef]

4. Vo, X.V. Trading of foreign investors and stock returns in an emerging market-Evidence from Vietnam. Int. Rev. Financ. Anal. 2017, 52, 88-93. [CrossRef]

5. Allen, F.; Qian, J.; Qian, M. Law, finance, and economic growth in China. J. Financ. Econ. 2005, 77, 57-116. [CrossRef]

6. Ye, J.; Fues, T. A Strong Voice for Global Sustainable Development: How China can Play a Leading Role in the Post-2015 Agenda. RePEc 2014, 2, 11-22.

7. Rosati, F.; Faria, L.G. Addressing the SDGs in sustainability reports: The relationship with institutional factors. J. Clean. Prod. 2019, 215, 1312-1326. [CrossRef]

8. Scott, L.; McGill, A. From Promise to Reality: Does Business Really Care about the SDGs; PriceWaterhouseCoopers: London, UK, 2018.

9. Courtis, J.K. Expanding the future financial corporate reporting package. Account. Forum 2000, 24, $248-263$. [CrossRef]

10. Griggs, D.; Nilsson, M.; Stevance, A.; McCollum, D. A Guide to SDG Interactions: From Science to Implementation; International Council for Science: Paris, France, 2017.

11. Deegan, C. Introduction: The legitimising effect of social and environmental disclosures-A theoretical foundation. Account. Audit. Account. J. 2002, 15, 282-311. [CrossRef]

12. Campbell, D.; Craven, B.; Shrives, P. Voluntary social reporting in three FTSE sectors: A comment on perception and legitimacy. Account. Audit. Account. J. 2003, 16, 558-581. [CrossRef]

13. Campbell, J.L. Why would corporations behave in socially responsible ways? An institutional theory of corporate social responsibility. Acad. Manag. Rev. 2007, 32, 946-967. [CrossRef]

14. Vo, X.V. Bank lending behavior in emerging markets. Financ. Res. Lett. 2018, 27, 129-134. [CrossRef]

15. Oliver, C. Determinants of interorganizational relationships: Integration and future directions. Acad. Manag. Rev. 1990, 15, 241-265. [CrossRef]

16. Ntim, C.G.; Soobaroyen, T. Corporate Governance and Performance in Socially Responsible Corporations: New Empirical Insights from a Neo-Institutional Framework. Corp. Gov. Int. Rev. 2013, 21, 468-494. [CrossRef]

17. Kolk, A.; Perego, P. Determinants of the adoption of sustainability assurance statements: An international investigation. Bus. Strat. Environ. 2008, 19, 182-198. [CrossRef]

18. Kuhn, B. Sustainable Development Discourses in China. J. Sustain. Dev. 2016, 9, 158. [CrossRef]

19. Wang, B.; Lyv, M.; Xing, J.; Zhou, Q.; Ding, M.; Shen, Y. Climate Change in the Chinese Mind: Survey Report 2017; China Center for Climate Change Communication: Beijing, China, 2017.

20. Cohen, M. A systematic review of urban sustainability assessment literature. Sustainability 2017, 9, 2048. [CrossRef]

21. Borys, T. Zrównoważony rozwój-jak rozpoznać ład zintegrowany. Probl. Ekorozw. 2011, 6, 75-81.

22. Vasconcellos Oliveira, R. Back to the Future: The potential of intergenerational justice for the achievement of the sustainable development goals. Sustainability 2018, 10, 427. [CrossRef]

23. UN. UN Documents: Gathering a Body of Global Agreements; UN: New York, NY, USA, 2016. 
24. UN. Agenda 21: Programme of Action for Sustainable Development Rio Declaration on Enviroment and Development Statement of Forest Principles the Final Text. In Proceedings of the Agreements Negotiated by Governments at the United Nations Conference on Environment and Development (UNCED), Rio de Janeiro, Brazil, 3-14 June 1992.

25. Division, U.N.S. Millennium Development Goals Indicators: The Official United Nations Site for the MDG Indicators; UNSD: New York, NY, USA, 2008.

26. Smith, R.J. A social worker's report from the United Nations Conference on Sustainable Development (Rio+ 20). Soc. Work 2013, 58, 369-372. [CrossRef]

27. Assembly, G. United Nations: Transforming Our World: The 2030 Agenda for Sustainable Development; UN: New York, NY, USA, 2015.

28. Raszkowski, A. The strategy of local development as a component of creative human capital development process. Pr. Nauk. Uniw. Ekon. We Wrocławiu 2015, 394, 135-143. [CrossRef]

29. Judson, G. Engaging Imagination in Environmental Education: Practical Strategies for Teachers; University of British Columbia Press: Vancouver, BC, Canada, 2017.

30. Caputo, F.; Veltri, S.; Venturelli, A. A Conceptual Model of Forces Driving the Introduction of a Sustainability Report in SMEs: Evidence from a Case Study. Int. Bus. Res. 2017, 10, 39. [CrossRef]

31. Baumgartner, R.J.; Korhonen, J. Strategic thinking for sustainable development. Sustain. Dev. 2010, 18, 71-75. [CrossRef]

32. Röller, L.-H.; Waverman, L. Telecommunications Infrastructure and Economic Development: A Simultaneous Approach. Am. Econ. Rev. 2001, 91, 909-923. [CrossRef]

33. Yigitcanlar, T.; Dur, F. Developing a Sustainability Assessment Model: The Sustainable Infrastructure, Land-Use, Environment and Transport Model. Sustainability 2010, 2, 321-340. [CrossRef]

34. Bulkeley, H.; Betsill, M. Rethinking Sustainable Cities: Multilevel Governance and the 'Urban' Politics of Climate Change. Environ. Politi. 2005, 14, 42-63. [CrossRef]

35. Plum, A.; Kaljee, L. Achieving Sustainable, Community-Based Health in Detroit Through Adaptation of the UNSDGs. Ann. Glob. Health 2017, 82, 981-990. [CrossRef]

36. Sharifi, A.; Yamagata, Y. On the suitability of assessment tools for guiding communities towards disaster resilience. Int. J. Disaster Risk Reduct. 2016, 18, 115-124. [CrossRef]

37. Mariño, R.; Banga, R.S. UN Sustainable Development Goals (SDGs): A time to act. J. Oral Res. 2016, 5, 5-6. [CrossRef]

38. Northrop, E.; Hana, B.; Sylvia, L.; Mathilde, B.; Ranping, S. Examining the Alignment between the Intended Nationally Determined Contributions and Sustainable Development Goals; World Resources Institute: Washington, DC, USA, 2016.

39. Ali, S.; Huda, M. Constructive Consumption: Bridging Livelihoods and Conservation in Democratic Societies. In CSR, Sustainability and Leadership; Gabriel, E., Ralph, B., Eds.; Routledge: Abington, UK, 2016.

40. Kosgey, H.S. Green Energy Strategies And United Nations Sustainable Development Goal Onaffordable Clean Energy At Kenya Electricity Generating Company Limited. IJRISS 2017, 3, 1.

41. UN. Sustainable Development Goals. Available online: https://sustainabledevelopment.un.org/ (accessed on 25 September 2017).

42. Gnanapragasam, A.; Cole, C.; Singh, J.; Cooper, T. Consumer Perspectives on Longevity and Reliability: A National Study of Purchasing Factors Across Eighteen Product Categories. Procedia CIRP 2018, 69, 910-915. [CrossRef]

43. Knox, J.H. Linking human rights and climate change at the United Nations. Harv. Environ. Law Rev. 2009, $33,477$.

44. Griggs, D.; Stafford-Smith, M.; Gaffney, O.; Rockström, J.; Öhman, M.C.; Shyamsundar, P.; Steffen, W.; Glaser, G.; Kanie, N.; Noble, I. Sustainable development goals for people and planet. Nature 2013, 495, 305-307. [CrossRef] [PubMed]

45. Information, UNDoP. The Millennium Development Goals Report 2005; United Nations Publications: New York, NY, USA, 2005.

46. Travis, P.; Bennett, S.; Haines, A.; Pang, T.; Bhutta, Z.; A Hyder, A.; Pielemeier, N.R.; Mills, A.; Evans, T. Overcoming health-systems constraints to achieve the Millennium Development Goals. Lancet 2004, 364, 900-906. [CrossRef] 
47. Lusk, E.J. Cognitive aspects of annual reports: Field independence/dependence. J. Account. Res. 1973, 11, 191-202. [CrossRef]

48. Healy, P.M.; Palepu, K.G. Information asymmetry, corporate disclosure, and the capital markets: A review of the empirical disclosure literature. J. Account. Econ. 2001, 31, 405-440. [CrossRef]

49. Campopiano, G.; De Massis, A. Corporate Social Responsibility Reporting: A Content Analysis in Family and Non-family Firms. J. Bus. Ethic. 2014, 129, 511-534. [CrossRef]

50. Krippendorff, K. Content Analysis: An Introduction to Its Methodology; Sage publications: New York, NY, USA, 2018.

51. Tagesson, T.; Blank, V.; Broberg, P.; Collin, S.-O.Y. What explains the extent and content of social and environmental disclosures on corporate websites: A study of social and environmental reporting in Swedish listed corporations. Corp. Soc. Responsib. Environ. Manag. 2009, 16, 352-364. [CrossRef]

52. Lee, K.-H.; Barker, M.; Mouasher, A. Is it even espoused? An exploratory study of commitment to sustainability as evidenced in vision, mission, and graduate attribute statements in Australian universities. J. Clean. Prod. 2013, 48, 20-28. [CrossRef]

53. Ford, L. Sustainable development goals: All you need to know. Guardian 2015, 19, 13-31.

54. Allen, C.; Metternicht, G.; Wiedmann, T. Initial progress in implementing the Sustainable Development Goals (SDGs): A review of evidence from countries. Sustain. Sci. 2018, 13, 1453-1467. [CrossRef]

55. Citizenship, C. Advancing the Sustainable Development Goals: Business Action and Millennials' Views; Corporate Citizenship: London, UK, 2016.

56. Hajer, M.; Nilsson, M.; Raworth, K.; Bakker, P.; Berkhout, F.; De Boer, Y.; Rockström, J.; Ludwig, K.; Kok, M. Beyond Cockpit-ism: Four Insights to Enhance the Transformative Potential of the Sustainable Development Goals. Sustainability 2015, 7, 1651-1660. [CrossRef]

(C) 2020 by the authors. Licensee MDPI, Basel, Switzerland. This article is an open access article distributed under the terms and conditions of the Creative Commons Attribution (CC BY) license (http://creativecommons.org/licenses/by/4.0/). 